\title{
지속가능발전목표(SDGs) 달성을 위한 민간파트너십과 재원메커니즘
}

\section{목 차}

I. 서론

II. 개발협력 최근 동향과 민간파트너십

1. Post-2015 개발의제와 지속가능발전목표(SDGs)

2. 아디스아바바 행동계획(Addis Ababa Action Agenda)

III. 개발협력에서의 민간과의 파트너십

1. 개발협력에서의 민간파트너십 특징

2. 민간파트너십 내 개발재원 모델의 유형

3. 개발재원메커니즘을 활용한 민간파트너십의 고려사항

IV. 타 해외 원조기관 사례:스웨덴 Sida

1. Sida의 민간파트너십 유형

2. Sida의 혁신적 개발재원 메커니즘

V. KOICA 민간파트너십 사업을 위한 제언

1. $\mathrm{KOICA}$ 의 민간파트너십 프로그램

2. KOICA에 제안하는 시사점 


\section{I. 서론}

MDGs에서 민간과의 파트너십 ${ }^{1)}$ 이슈는 8번 '개발을 위한 글로벌파트너십' 목표 아래 세부목표 에서 언급은 되어 있으나, 이는 정보통신기술 분야에 한정되어 있었다. 그러나, 2002년 몬테레이, 2008년 도하에서 열린 제 1,2 차 개발재원총회에서 개발 목표 달성을 위한 민간재원 동원의 필요성 을 제시하면서 효과적인 재원 활용을 위한 민간과의 파트너십 의제는 주목을 받기 시작하였다. 2011 년 HLF-4 부산회의에서는 민간부문이 공식적인 이해관계자로 참여하고 결과물인 부산파트너십을 통해 개발협력과 민간부문 간의 강력한 관계수립을 제안함으로써 민간파트너십의 중요성은 자연스 레 개발협력의 담론에서 자리 잡게 되었다.

오는 9월 28일 출범을 앞두고 있는 Post-2015 개발의제와 지속가능발전목표(SDGs) 역시 포괄적 인 경제성장, 품위 있는 일자리 창출, 지속가능한 인프라 개발, 금융서비스의 접근성 향상 등 민간부 문과의 협력이 필요한 목표들이 다수 포함되어 있으며, 경제 · 사회 · 환경을 아우르는 폭넓은 발전 목 표 달성을 위해서는 보다 많은 재원을 마련해야 하는 과제를 안고 있다. 더욱이 몬테레이 이후 선진공 여국의 ODA 이행약속에 대한 요구는 계속 되고 있음에도 불구하고 ODA와 OOF는 감소 추세에 있으 며, 반면 해외직접투자(FDI)와 송금 등의 민간재원의 비중은 급속도로 증가하였다. 따라서, ODA를 촉매제로 하여 민간 재원을 동원하자는 논의가 활발하게 진행되었으며 올해 7월에 열린 제 3 차 개발재 원총회에서 역시 $\mathrm{ODA}$ 를 활용한 민간 재원 동원에 대한 여러 이니셔티브가 소개되기도 하였다.

개발협력에 있어 민간파트너십의 유형 역시 시대에 따라 다양한 형태로 변화되어 왔다. 민관협력 (Public-Private Partnership)이라는 개념은 전통적인 정부 간 채널을 통한 원조방식과 비교하여 혁신적인 방법으로 주목을 받았으며, 이후 BoP 비즈니스, 공유가치창출(creating shared value; $\mathrm{CSV}$ ), 포용적 비즈니스(inclusive business)와 같은 여러 개념이 제시되고 이를 토대로 하는 사업 모델을 창출함으로써 민간파트너십의 혁신은 지속되었다. 최근에는 $\mathrm{ODA}$ 를 활용한 민간부문 투자 지원 및 개발재원 동원에 관심이 집중되면서 여러 원조기관에서 챌린지펀드(challenge fund), 개발 영향채권(development impact bond) 등과 같은 혁신적 개발재원 모델을 도입하고 있다.

$\mathrm{KOICA}$ 역시 민간파트너십 사업모델로 글로벌 CSR 프로그램부터 CSV개념을 도입한 혁신적 민 관협력 비즈니스 모델 등을 발굴하였으며, 최근에는 임팩트 투자(impact investment)모델을 도입

1) 본 연구의 주제인 민관협력은 Public-private Partnership의 개념에 한정짓지 않고 PPP를 포함한 개발협력에 있어 다양한 민간과의 파트너십 유형을 의미한다. 따라서 본문에서는 민관협력이라는 용어 대신에 민간파트너십 혹은 민 간과의 파트너십이라는 표현을 사용하였다. 
한 사업을 착수하였다. 이와 같이 $\mathrm{KOICA}$ 는 새로운 형태의 민간파트너십 사업모델을 수립하기 위해 다양한 시도를 해왔으며, 무상원조기관으로서 앞으로도 진행될 민간파트너십 모델과 개발재원 메커 니즘 관련 논의를 반영해야 하는 역할을 가지고 있다.

따라서 본 연구는 원조기관의 민간파트너십 특히 개발재원관련 메커니즘에 중점을 두고, 지속가 능발전목표(SDGs)와 아디스아바바 개발재원총회의 논의를 통해 민간파트너십에 관한 최근 동향을 살피고, 다양한 민간파트너십 모델 및 재원메커니즘을 활용하고 있는 스웨덴 Sida의 사례를 조사함 으로써 SDGs 달성을 위한 민간파트너십과 관련하여 $\mathrm{KOICA}$ 에 시사점을 제안하기 위한 목적으로 작 성되었다.

제I장

\section{II. 개발협력 최근 동향과 민간파트너십}

\section{Post-2015 개발의제와 지속가능발전목표(SDGs)}

사회 발전의 이슈만을 다룬 MDGs의 한계를 보완하기 위해 SDGs에서는 포용적 경제발전과 관련 한 여러 목표가 제시되었다. 이에 따라 민간부문의 개발 과정 참여 증가와 공공-민간 파트너십의 확 장은 자연스럽게 따라올 수밖에 없는 현상이 되었다. SDGs에서 제시한 17 개의 목표를 자세히 살펴 보면, 교육, 보건, 농업, 에너지 등의 섹터부터 성 평등, 환경 등의 크로스커팅 이슈까지 다양한 분야 에서 민간과의 파트너십을 만들어낼 수 있는 접점은 매우 크다고 볼 수 있다. 이 중에서도 특히, 8번 목표 '포괄적이고 지속가능한 경제성장과 완전하고 생산적인 고용, 그리고 모두를 위한 양질의 일자 리 제공', 9번 목표 ‘회복(복원)가능한 인프라 건설, 포용적이고 지속가능한 산업화 및 혁신촉진', 12 번 목표 '지속가능한 소비와 생산양식의 보장' 등은 민간과의 파트너십이 더욱 중요하게 작용하는 목 표라고 볼 수 있다.

글로벌 파트너십과 관련한 MDGs의 8번 목표가 정부, 기업, 시민사회 등 개발에 참여하는 주요 이해관계자의 역할 및 파트너십 메커니즘을 담고 있지 않다는 비판을 받자 이번 SDGs에서는 목표 달성을 위한 이행수단과 파트너십에 대해 보다 구체적으로 제시하려고 노력하였다. 따라서, SDG 의 기본 골자를 보면 1 16번 각각의 목표 하 세부목표들 중 이행수단 관련 세부목표를 포함하고 있 으며, 17 번 목표에서는 별도로 '지속가능발전을 위한 이행수단과 글로벌파트너십 강화(strengthen the means of implementation and global partnership for sustainable development)'라는 주 제로 목표를 달성하기 위한 이행수단과 파트너십을 다루고, 세부목표를 개발재원(finance), 기술 (technology), 역량배양(capacity building), 무역(trade), 시스템 이슈(systemic Issue)로 구분하 
여 19 개로 구성하고 있다.

이들 대부분 역시 민간파트너십과 밀접한 관련이 있으나 특히 개발재원과 관련해서는 민간과 협 력할 수 있는 접점이 매우 중요하다. 17번 목표 내 세부목표에서는 다양한 방식을 통해 추가적인 재 원을 동원해야 함과 최빈국에 투자촉진 체제를 도입하고 시행해야 할 것을 제시했다. 또한, 개발재 원에 대한 중요성은 SDGs의 장을 여는 1 번째 목표인 '모든 형태의 빈곤종식'에서도 언급하고 있다. 1 번 목표의 이행수단 관련 세부목표 '1a. 개발도상국, 특히 최빈국이 모든 형태의 빈곤을 종식하기 위한 프로그램과 정책을 이행하기 위해 충분하고 예측 가능한 도구를 제공하기 위해 개발협력 강화 를 포함한 다양한 자원의 활용보장'의 첫 번째 검토지표는 '1. 정부, 민간부문, 개발 파트너들을 포함 하여 빈곤감소를 위해 동원되고 지출된 재원'으로서 이는 기존의 ODA 재원 규모를 넘어 민간부문과 의 파트너십을 통해 빈곤 감소를 위한 재원 동원을 촉진해야 함을 언급하고 있다.

\section{2. 아디스아바바 행동계획(Addis Ababa Action Agenda)}

오는 9월 SDGs의 선언을 앞두고 7월 13일 16일까지 아디스아바바에서 열린 개발재원총회는 몬 테레이와 도하에 이어 세 번째로 개최된 개발재원총회로서 그 동안의 개발재원에 대한 논의와 그 이 행상황을 점검하고, 다가오는 지속가능발전 목표 달성 재원마련을 위한 합의 마련의 목적으로 기획 되었다. 기존의 1,2 차 개발재원총회가 MDGs 수립 이후 후속적으로 개최된 것과는 달리 이번 3 차 개발재원총회는 SDGs 출범 전 개최함으로써 개발재원 마련에 대한 논의의 중요성을 가늠하게 하였 다. 본 총회의 결과문서인 '아디스아바바 행동계획(addis ababa action agenda)'은 Post-2015 개 발의제 최종문안에도 차용되어 SDGs 이행을 위한 개발재원 마련의 근거로써 활용될 예정에 있다.

아디스아바바 행동계획은 7 가지 행동 분야를 통해 세수확보를 통한 개도국 국내 재원 동원, 국내 외 민간 재원 활용의 중요성, $\mathrm{ODA}$ 공약 이행 및 국제개발협력 우선 지원 분야 협의, 개발 동력을 위 한 무역 촉진, 과학기술혁신과 역량 강화, 제도 신설과 모니터링 및 책무성 강화 및 글로벌 파트너십 등을 제시하였다. 이 중 민간과의 파트너십 이슈는 뜨거운 관심사중 하나였다. '국내외 민간 기업과 재원(domestic and international private business and finance)'에서는 개도국 중소기업 금융지 원, 이주자송금수수료 인하, 국내 자본시장 개발, 해외직접투자 촉진 등 여러 방안들이 제시되었으 며, '국제개발협력(international development cooperation)'에 있어서 역시 ODA의 규모적 한계 를 인식하고 SDGs 달성을 위해 ODA를 촉매제로 활용함으로써 필요한 개발 재원의 간극을 메워야 한다는 의견이 포함되었다. 
이와 관련하여 아디스아바바 개발재원총회에서는 지난 4월 여러 개발은행이 이공동으로 발표한 "from billions to trillions"라는 성명에 이은 부대행사를 개최하며, SDGs 달성을 위해 다양한 민 간 및 공적재원을 활용하여 필요한 투자를 효과적으로 수행하는 방안을 논의했다(박수영 · 오수현 2015). 또한, 아디스아바바 행동계획 내에서도 다양한 금융수단 메커니즘, 위험 완화 수단 및 공동 출자 기금 등이 인프라 자금 마련에 있어 공공 및 민간 투자가 핵심 역할을 수행하고 있음을 인지하 였으며, 민관협력을 포함한 혼합금융 수단들이 투자고유위험을 낮추고, 지속가능발전을 위해 추가 적인 민간 부문 자금마련을 기여한다고 보았다. 다만, 혼합금융도구의 적합한 구조와 사용이 세심히 고려되고 명확한 책무성 메커니즘을 포함할 것을 언급하였다.

$\mathrm{ODA}$ 를 포함한 국제 공공 재원의 영향력 있게 사용하기 위해 민간재원의 추가적인 동원에 대한 촉매제 역할을 수행해야 함을 밝히고, 혼합 및 공동출자금융에 있어 위험을 분담함으로써 민간 부 문 개발을 지원하는 인프라와 기타 투자를 위한 추가적 재원을 동원하는데 데 사용될 수 있다고 하였 다. 또한, 혁신적 개발재원 마련에 대한 기존의 진척사항을 긍정적으로 평가하며 녹색채권, 백신채 권, 삼자간 대출과 풀메커니즘(pull mechanisms) $)^{3)}$ 및 탄소가격 메커니즘과 같은 공적재원과 민간 재원을 결합하는 모델에 관해 지속적으로 연구해나갈 것을 권장하고 있다.

이와 같이 향후 Post-2015를 이끌어갈 SDGs와 아디스아바바행동계획을 살펴본 결과, 민간과의 파트너십을 위한 개발협력 관련 기관의 관심은 더욱 확대될 것이며, 특히 민간개발재원 동원에 대해 서는 앞으로도 많은 연구와 노력이 지속될 것으로 보인다. 따라서, 다음 장에서는 개발협력에서의 민간파트너십의 최근 동향과 유형, 특히 개발재원 관련 메커니즘에 대해 자세히 알아보도록 한다.

\section{III. 개발협력에서의 민간과의 파트너십}

\section{1. 개발협력에서의 민간파트너십 특징}

민간부문 파트너십과 관련한 다양한 개념과 사업 유형은 지속적으로 등장하기 시작하였는데, 그

2) 세계은행(World Bank), 국제통화기금(International Monetary Fund; IMF), 아프리카개발은행(African Development Bank; AfDB), 아시아개발은행(Asian Development Bank; ADB), 유럽부흥은행(European Bank for Reconstruction and Development, EBRD), 유럽투자은행(European Investment Bank, EIB), 미주개발은행(Inter-American Development Bank; IDB)등이 참여함.

3) 민간부문이 설정된 목표를 향해 노력하도록 촉진하는 방식으로써, 증여모델을 활용하는 전통적 개발 방식과는 대조 적으로 개발 목표에 대한 특정 진로를 결정하기 위해서 구체적 투입과 절차보다는 사전에 확정한 성과달성에 대해 보상 한다. 
중 가장 대표적인 것은 민관협력(public-private partnership)으로서 정부에 제공하는 병원, 학교, 철도, 도로, 수도 및 하수처리시설 등의 사회 인프라 설립과 서비스 제공에 있어 민간 부문이 참여하 고 제공하는 방식을 의미한다. 민관협력(public-private partnership)을 통해 공공부문 인프라 공 급에 민간 투자자가 참여하는 것은 약 20년 전부터 여러 국가에 의해 채택된 새로운 트렌드였으며, 공공서비스 서비스 인프라 부족을 해결하기 위해 ODA로 부족한 재원을 민간 부문에 재원 조달의 일부 의무를 전가하고 제공된 서비스의 품질 및 효율성을 향상시키는 데 그 목적을 두었다(최민경, 2008).

그 이후에는 주목할 동향 중 하나는 빈곤 완화의 긍정적 영향을 강화하기 위해 기업의 핵심 사업 을 접목하자는 주장이 강조되면서 $\mathrm{BoP}$ 비즈니스(base of the pyramid business) ${ }^{4}$, 공유가치창출 $(\mathrm{CSV})^{5)}$, 포용적 비즈니스(inclusive business) ${ }^{6}$ 등 다양한 민간파트너십의 개념이 나타났다. 이는 기존의 소극적 형태의 '기업의 사회적 책임(corporate social responsibility; CSR)'을 넘어 보다 책임감 있고, 지속가능하며, 포용적이고, 친빈곤적이며, 기업과 빈곤층 모두에게 긍정적 영향을 가 져오는 윈-윈 형태를 의미하는 것이기도 하다.

또한, 앞에서 언급한 바와 같이 지속가능한 발전을 이루기 위해서는 필요한 거대한 재원의 간극 을 메우기 위하여 $\mathrm{ODA}$ 를 촉매제로 하여 민간 투자를 유치하고 재원을 동원하기 위해 원조기관 차 원의 노력들도 생겨나기 시작하였다. 지난 십년 간, 공여기관들은 민간부문 투자를 위한 파트너십과 지원에 그들의 대부분의 노력을 기울여 온 반면, 최근의 동향은 개발을 위한 혼합 대출 및 증여를 통 한 민간재원 레버리지를 위한 노력으로 그 중점이 모이고 있다(ECDPM, 2014). 따라서, 이와 관련 한 내용은 다음 장에서 좀 더 자세히 알아보기로 하겠다.

\section{2. 민간파트너십 내 개발재원 모델의 유형}

최근 개발재원에 대한 논의가 가속화되면서 개발협력에서의 민간파트너십에 있어 공여기관, 기 업, $\mathrm{CSO}$ 등이 이들 관련 사업에 참여하고 있으며, 구체적으로 어떤 목적으로 재원 메커니즘을 활용

4) 1998년 미국의 C.K. Prahalad 교수와 Stuart L. Hart 교수가 발표한 개념으로써 빈곤층을 수혜의 대상이 아닌 소비 자로 보았으며, 약 50 억 명으로 추산되는 이들의 구매력을 감안하여 BoP 비즈니스모델을 수립함으로써 기업의 이 익과 빈곤층의 빈곤 감소에 함께 기여할 수 있다고 보았다.

5) Michael Porter가 2006년 Harbard Business Review를 통해 제시한 개념으로써 기존의 CSR을 넘어 기업과 사회 가 함께 가치를 창출할 수 있도록 기업의 전략을 수립해야 한다는 데에서 출발하였다.

6) UNDP, DFID와 같은 개발협력기관에서 사용하는 개념으로써 빈곤층을 생산자 및 소비자등 기업활동의 가치사슬에 서 보다 많이 포함시킴으로써 그들의 빈곤감소에 긍정적인 영향을 미칠 수 있도록 하는 비즈니스를 의미한다. 
하는지, 재원메커니즘 수단의 종류는 무엇인지에 따라 다양한 유형이 제시되고 있다. 선진 양자원조 기관들은 협력국의 포용적 경제 발전을 위해 개발도상국 내 민간 기업 투자, 협력국에 진출하는 자 국 기업의 자금 지원을 하고 있으며 이를 위해 챌린지펀드, 임팩트투자, 사회책임투자, 차관, 보증 등 다양한 층위의 개발재원 메커니즘을 활용하고 있다.

다양한 층위의 개발재원 메커니즘을 활용한 민간파트너십의 유형을 분류하기 위하여 유엔 지속가 능 발전 재원조달에 관한 정부 간 전문 위원회(the UN intergovernmental committee of experts on sustainable development financing; ICESDF)에서는 크게 다음과 같이 두 개의 카테고리를 제안한다.

〈표 1〉 개발재원 관련 민간부문 파트너십

1. 개발을 위한 민간부문 투자 (private sector investment for development)

국제개발파트너가 개발목적으로 (국제)민간부문 활동에 참여하는 경우
2. 개발을 위한 민간부문 재원 (private sector finance for development)

$\mathrm{ODA}$ 를 활용하여 민간부문 재원을 레버지링하는 경우

출처: ECDPM, 2014

첫째는, 민간 투자를 촉진하는 파트너십으로서 국제개발파트너가 개발을 목적으로 민간부문 활 동에 참여하는 경우를 말한다. 주로 민간에 투자하는 공여기관의 파트너십모델에 있어서는 영국 DfID, 호주 AusAID(현 DFAT), 스웨덴 Sida는 챌린지펀드(challenge fund)라는 이름으로 개도 국 기업에 투자하는 메커니즘을 활용하였으며, 이 밖에도 혁신펀드(innovation fund), 매치메이킹 제도(match-making facility)등이 있다. 또한, 해당 카테고리의 다자파트너십 형태로는 Global Alliane for Improved Nutrition(GAIN)등을 들 수 있다.

챌린지펀드(challenge fund)는 원조기관에서 보건, 교육, 인프라, 환경 등 개발관련 과제를 해 결하려는 목적의 민간 프로젝트에 경쟁과정을 거쳐 자원을 지원하는 파트너십 수단을 말한다. 이 는 증여 형태뿐만 아니라 양허성 차관, 기술지원 및 지식 전수 등을 포함하기도 한다. 혁신펀드 (innovation fund)는 챌린지펀드의 일환으로 개발 도전과제에 대해 혁신적인 해결방안을 제시하 는 기업의 역량강화 목적으로 사용되며, 예로는 DfID의 Business Innovation Facility와 Sida의 Innovation against Poverty를 들 수 있다. 
매치메이킹기금(match-making facility)는 해외기업과 개도국 기업을 연계하여 상업적 협력 을 증대하고 비즈니스 파트너십을 촉진하는데 목적을 두는 수단으로써 DANIDA의 비즈니스 파트너 십 프로그램(business partnership programme)이 대표적이다. 이 프로그램은 덴마크 기업의 지식 과 기술을 협력국 내 기업 파트너에 이전하여 고용을 창출하고, 경쟁력을 강화하는데 중점을 두었다. DANIDA의 재원 지원 비중에 있어 파트너를 확보하고 준비하는 단계에는 최대 $75 \%$ 를, 사업 실행에 는 최대 $50 \%$ 까지 지원하고 있다. 본 모델은 협력국 기업 지원에 있어 직접 투자 대비 정치적 민감성 에 상대적으로 덜하다는 장점이 있다고 평가된다.

두 번째는 공적자원을 촉매제로 하여 금융수단을 통한 민간재원 동원 목적의 파트너십 형태를 의 미한다. 그 유형으로는 혼합금융, 성과기반원조(OBA), $\mathrm{ODA}$ 전기이행, 통화스왑, 보증 등이 있으며 이들 개념에 대해서는 다음의 〈표 2〉에서 간략하게 설명하고 있다.

\section{〈표 2〉 민간파트너십 재원메커니즘의 유형}

\begin{tabular}{|c|c|}
\hline $\begin{array}{l}\text { 혼합 } \\
\text { Blending }\end{array}$ & $\begin{array}{l}\text { 준투자(sub-investment)등급 프로젝트가 이익을 낼 수 있게 하기 위한 대출과 증여의 } \\
\text { 상호보완적 혼합 }\end{array}$ \\
\hline $\begin{array}{l}\text { 성과기반원조 } \\
\text { Output-Based Aid; } \\
\text { OBA }\end{array}$ & $\begin{array}{l}\text { 민간부문이 특정 수혜자에게 사회적 서비스를 제공하기 위한 자금 혹은 보조금을 받 } \\
\text { 는 계약상의 협정 }\end{array}$ \\
\hline $\begin{array}{l}\text { 민간자금공적지원 } \\
\text { Official Support for } \\
\text { Private Flows }\end{array}$ & $\begin{array}{l}\text { 개도국 내 활동을 발전시키고 규모화하기 위해 새로운 수익을 창출하고 민간투자 레 } \\
\text { 버리징 하기 위한 개발펀드 }\end{array}$ \\
\hline $\begin{array}{l}\text { ODA 전기이행 } \\
\text { Front-loading of } \\
\text { ODA }\end{array}$ & $\begin{array}{l}\text { 장기적 법적 구속력이 있는 ODA 책무에 의해 지원되는 공공채권 발행에 의한 국제자 } \\
\text { 본시장의 펀드를 모으는데 활용 }\end{array}$ \\
\hline $\begin{array}{l}\text { 개발영향채권 } \\
\text { Development Impact } \\
\text { Bonds }\end{array}$ & $\begin{array}{l}\text { 사전 정의된 특정 개발도전과제를 극복하기 위한 잠재력 있는 민간 프로젝트에 선불로 } \\
\text { 지급된 공공 혹은 민간 자금을 의미함. 만약 프로젝트가 목표를 달성 시, 민간 행위자 } \\
\text { 는 공공 자금제공자에게 보상을 받고 실패의 경우 투자자는 원금 위험을 감수해야 함. }\end{array}$ \\
\hline $\begin{array}{l}\text { 통화스왑 } \\
\text { Currency Swaps }\end{array}$ & 동의된 이자율, 금액 및 만기율 하 두 통화의 교환 \\
\hline $\begin{array}{l}\text { 금융보증기능 } \\
\text { Financial } \\
\text { guarantees } \\
\text { functions }\end{array}$ & $\begin{array}{l}\text { 원금 및 이자 지급이 채무불이행의 경우 지급되는 보증이 공공 발행인에 의해 지원되 } \\
\text { 는 채권 }\end{array}$ \\
\hline $\begin{array}{l}\text { 투자대출 } \\
\text { Investment Loans }\end{array}$ & $\begin{array}{l}\text { 개발은행/기관이 은행에 의해 발전에 긍정적 영향을 주는 것으로 간주되는 특정 운영 } \\
\text { 혹은 프로젝트를 위해 기업에 자금을 빌려줄 때 사용하는 수단 }\end{array}$ \\
\hline
\end{tabular}




\begin{tabular}{l|l}
\hline $\begin{array}{l}\text { 신디케이티드론 } \\
\text { Syndicated loans }\end{array}$ & $\begin{array}{l}\text { 개발은행/기관이 다자간투자자 프로젝트의 주요 기여자 혹은 조정자로써 참여하는 경 } \\
\text { 우 사용하는 수단 }\end{array}$ \\
\hline $\begin{array}{l}\text { 금융중개대출 } \\
\text { Financial } \\
\text { intermediary loans }\end{array}$ & $\begin{array}{l}\text { 개발은행/기관이 금융 중개자에게 자본을 대출하는 경우, 주로 이를 고객에게 다시 대 } \\
\text { 출는 민간은행이 금융중개자임. }\end{array}$ \\
\hline $\begin{array}{l}\text { 양허성차관 } \\
\text { Concessional loans }\end{array}$ & 시장가격 하 이자율로 차입된 대출 \\
\hline $\begin{array}{l}\text { 직접지분 } \\
\text { Direct equities }\end{array}$ & $\begin{array}{l}\text { 개발은행/기관이 주식 구매에 의해 기업에 직접적으로 투자한 후 기업 내 주주가 되 } \\
\text { 경우 }\end{array}$ \\
\hline $\begin{array}{l}\text { 민간지분펀드 } \\
\text { Private equity funds }\end{array}$ & $\begin{array}{l}\text { 개발은행/기관이 주식에 투자하고 민간펀드매니저에 의해 관리되는 뮤추얼펀드에 투 } \\
\text { 자하는 경우 }\end{array}$ \\
\hline
\end{tabular}

출처: 저자작성/참고문헌: ECDPM, 2014

\section{제I장}

\section{3. 개발재원 메커니즘을 활용한 민간파트너십의 고려사항}

성공적이고 혁신적인 개발재원 관련 민간파트너십 모델을 수립하기 위해서는 다음과 같이 몇 가 지 고려해야 할 사항들이 있다고 생각한다. 첫째는, 공적재원을 촉매제로 활용하여 가능한 많은 민 간재원을 동원할 수 있어야 하며, 둘째, 동원된 자원을 활용하여 경제 · 사회 · 환경 분야에 지속가능 한 발전 목적을 달성해야 한다. 셋째는 해당 사업에 참여하는 각각의 이해관계자의 핵심 역량을 효 율적으로 활용하고 조정함으로써 파트너십의 효율성이 극대화할 수 있어야 하며, 마지막으로 효과적 인 위험 분산 및 관리를 통하여 민간투자자, 개도국 모두에게 가져올 수 있는 위험을 완화시킬 수 있 어야 한다.

이 중, 공적재원의 촉매제로서의 역할에 대한 측정 및 분석은 핵심 고려사항으로써 공적자원이 투 입됨으로써 민간재원을 동원할 수 있었다고 입증하는 추가성(additionality)이슈와 얼마나 많은 민 간재원을 동원할 수 있었는가의 규모와 연관이 있다. 또한, 위험 관리 면에 있어서도 공적재원은 개 도국 투자의 고위험으로 인해 민간투자가가 기피하는 최빈국 투자에 보증수단의 역할을 함으로써 위 험을 분산시키는 역할을 하며, 또한 개도국에 장기적 민간재원을 유입시키려는 노력을 통해 지속가 능한 발전에 기여할 수 있다. 또한 이는 협력국 빈곤감소 및 발전에 긍정적인 영향을 미쳤다는 개발 성과를 국민에게 입증해야 하는 책임과도 관련이 된다. 이를 위한 공적 재원의 사용은 조심스럽게 평가되어야 하는데 이는 투입된 공적재원에 대한 기록을 추적하는 것뿐만 아니라 해당 공적재원이 다른 영역에 사용되었을 때 가져올 수 있는 긍정적 영향이 더 클 수 있는 경우, 혹은 다른 국가나 원 조프로그램에 투입되었을 때 더 큰 개발성과를 가져올 수 있는 이슈에 대응하기 위해서이기도 하다 (Eurodad, 2015). 
그 외에도 공적재원의 투입이 시장의 왜곡을 가져오지는 않는지, 공적재원을 활용한 민간재원의 동원이 순수한 민간재원이 들어올 수 있는 여지를 밀어내고 있는 건 아닌지(crowding-out), 민간재 원이 과도하게 들어오면서 생길 수 있는 채무위험의 증가 등도 함께 고려되어야 할 사항들이다.

\section{IV. 타 원조기관의 민간파트너십 사례 : 스웨덴 Sida}

\section{Sida의 민간파트너십 유형}

스웨덴의 양자원조기관인 스웨덴국제개발협력청(Swedish International Development Cooperation Agency; 이하 Sida)은 민간과의 협력에 있어 다양한 모델을 활용하기 위해 노력해왔 다. 현재 Sida의 민간과의 협력 모델은 공공-민간 개발파트너십, 챌린지 펀드, 변화의 동력, 혁신적 재원조달 등 4 가지로 나눌 수 있다.

첫째, 공공-민간 개발 파트너십(public private development partnerships)은 주로 대기업과 윈-윈 목적으로 협력하여 개발프로젝트에 공동으로 자금을 조달하며, 기업은 항상 프로젝트 투자의 최소 $50 \%$ 이상 기여할 수 있도록 하고 있다.

둘째, 앞서 소개한 챌린지 펀드 Challenge Funds로서 이 모델은 BoP 비즈니스 컨셉을 가진 중 소기업들이 재원 조달을 위해 경쟁을 하여 Sida의 지원을 받는 형태이다. Sida가 실시한 첫 번째 챌 린지 펀드는 빈곤에 대응하는 혁신(innovations against perverty)프로그램으로 도움이 필요한 혁 신적 소규모 기업가들에게 재원을 매칭해주는 모델로써 2011년에 처음 시작하였다. 또한, 새롭고 혁 신적인 농업비즈니스 아이디어를 통해 사업을 수행하는 아프리카기업을 위한 아프리카기업 챌린지 펀드(Africa Enterprise Challenge Fund; AECF)도 있다.

세 번째 분야는 변화의 동력(drivers of change) 모델로서 주로 스웨덴 내 다국적기업과의 파트 너십을 통해 더 나은 비즈니스 규범에 대한 인식 증대 및 지속가능한 비즈니스를 위한 기준 수립 및 시장에 긍정적 변화를 가져오는 것을 목표로 한다. 사례로써, 스웨덴 의류기업은 $\mathrm{H} \& \mathrm{M}$, 국제노동기 구(ILO)와 함께 방글라데시에서 노동환경 개선을 위한 인식 개선 사업 등을 진행하였다.

마지막은 혁신적 재원조달(innovative financing) 모델로서 개발 성과를 위한 민간 자본을 동원 하는 방법으로써 주로 Sida의 개발차관, 환경 차관 및 보증 계약 등을 활용하며, 이에 대해서는 별도 의 장에서 좀 더 자세히 알아보기로 한다. 


\section{Sida의 혁신적 개발재원 메커니즘}

스웨덴개발협력청은 최근 혁신적 개발재원에 대해 다음과 같은 정의를 내리고 있다. '혁신적인 재 원조달(innovative financing)'은 새로운 형태의 금융 솔루션을 통해 개발을 위한 시장 기반의 또는 자선적 형태의 민간 자본 자원을 동원하는 것을 목표로 한다. 여기서 언급하는 금융 솔루션은 대표 적으로 개발차관 및 보증방식(guarantee arrangements)이 있다.

Sida의 개발차관(development loans)은 저소득국 또는 중소득국의 거대한 투자수요를 무상원 조만으로는 해결할 수 없기에 무상원조와 시장 재원을 연계함으로써 경제 발전을 위해 동원 가능한 자원을 확장하고 레버리징하는 기회를 제공한다. Sida는 차관제도(loan facility)를 보완하기 위해 서 무상원조를 함께 제공하며, 지원비율의 범위는 전체펀딩에서 무상원조 $35 \sim 80 \%$, 시장조달대출 $65 \sim 20 \%$ 으로 이루어진다. 시장 조달 대출은 은행 혹은 다자금융기구에 의해 발행되며, Sida는 아 시아개발은행(ADB), 유럽부흥개발은행(EBRD), 성과기반원조 글로벌파트너십(global partnership on output-based aid; GPOBA), IFC, USAID등 여러 공여파트너들과 긴밀히 협력하여 효율적으 로 위험을 분산하고 성공사례를 공유하고 있다. 또한, 스웨덴 정부는 개발차관과 보증의 활용을 수 용하는 환경 차관 및 보증에 대한 특별 전략을 수립하여 2013년 예산 기준 약 2 억5천만 스웨덴크로 나(약 356억 원)를 환경차관(environment loans)에 배정하였으며, 이들 차관은 주로 에너지 효율성 및 재생가능한 에너지, 물, 하수처리시설, 폐기물 및 운송 관리 향상을 목적으로 하고 있다.

Sida의 보증(guarangee arrangement)은 유연한 금융 수단으로 빈곤 감소를 돕기 위한 경제 성 장을 촉진하기 위한 목적으로 파트너 국가의 국내 자본을 포함한 자본의 동원을 가능하게 한다. 보 증은 투자자와 기업에게 자금을 대출하기를 원하는 금융기관을 위한 보험의 성격을 지니며, Sida는 다른 시장 위험 관련 손실에 대비하여 프로젝트를 유지하기 위해 채권자의 위험을 분산하는 것을 돕 는다. 만약 위험이 발생하여 채무자가 대출을 상환할 수 없을 때, Sida는 손실의 일부를 보장한다. $\mathrm{Sida}$ 는 $\mathrm{ADB}, \mathrm{USAID}$ 와 같은 주요 파트너와 긴밀히 협력하고 있으며, 보증은 에너지, 교육, 민주적 거버넌스, 인프라, 보건, 비즈니스 개발 등을 포함하여 다양한 분야에 사용된다.

Sida는 개발재원의 메커니즘이 혁신적인지를 측정하기 위해 레버지링, 촉매성, 개척성, 반복가능 성, 측정가능성, 재활용가능성 등의 6 가지 측정요소를 두고 있으며, 구체적인 내용은 다음과 같다. 
〈표 3〉Sida의 혁신적 개발재원을 위한 6 가지 측정요소

\begin{tabular}{l|l}
\hline \multicolumn{1}{c|}{ 측정요소 } & \multicolumn{1}{c}{ 내용 } \\
\hline $\begin{array}{l}\text { 1. 레버리징 } \\
\text { Leveraging }\end{array}$ & $\begin{array}{l}\text { 스웨덴 ODA는 ODA에 추가하여, 더 높은 정도의 레버리지로, 더 나은 형태의 } \\
\text { 재원을 조달한다. }\end{array}$ \\
\hline $\begin{array}{l}\text { 2. 촉매적 } \\
\text { Catalytic }\end{array}$ & Sida의 참여는 다른 행위자 혹은 다른 맥락의 자금 사용을 촉진한다. \\
\hline $\begin{array}{l}\text { 3. 개척적 } \\
\text { Pioneering }\end{array}$ & Sida는 자금 조달 및 재원마련 메커니즘의 새로운 방법을 제시한다. \\
\hline $\begin{array}{l}\text { 4. 반복 가능한 } \\
\text { Replicable }\end{array}$ & 규모를 확대하거나 재적용한다. \\
\hline $\begin{array}{l}\text { 5. 측정 가능한 } \\
\text { Measurable }\end{array}$ & 기대결과를 사전 정의하고 결과의 달성 정도를 사후 결정한다. \\
\hline $\begin{array}{l}\text { 6. 재활용가능 자본 } \\
\text { Recyclable capital }\end{array}$ & $\begin{array}{l}\text { Sida의 보증 유보금의 재사용 혹은 공여자가 기여한 자금이 수행 주체에 돌려주거나 } \\
\text { 재배치한다. }\end{array}$ \\
\hline
\end{tabular}

출처: Devfin Advisers, 2014

Sida는 보증과 관련한 주요 원칙 및 조건을 다음과 제시하고 있다. 첫째는, 추가성(additionality)으로 Sida가 보증 발행의 가능성을 고려할 때 보증을 발행하는 다른 행위자가 있을 가능성이 없는 상황에 참여해야 한다. 둘째, Sida는 항상 관련 기관과 위험분산(risk-sharing)하며 절대 위험 전체를 떠안지 않는다. 셋째는, 위험반영프리미엄(risk reflecting premium)으로 Sida는 보증 발행 을 위해 위험반영프리미엄을 청구하며, 이는 스웨덴 정부채권 오피스 내 금융계좌에 예치된다. 만약 기금에서 손실이 발생한 경우 보증은 요구되며, Sida의 손실 공유는 보증 유보금에 의해 커버된다. 마지막은 비왜곡성(non-distortionary)으로 프로젝트를 평가할 때, Sida가 참여하는 곳에 경쟁의 시장 폐해 혹은 왜곡에 대한 미미한 위험이 있다는 것을 보장해야만 한다.

이 밖에도 1990년대 말 스웨덴 정부가 보증 도구나 또는 정부 보조금과 결합하여 적용한 첫 번째 손실 적용(first-loss applications), 개발 촉진을 위한 전기 이행, 보증 도구, 또는 정부 보조금과의 결합을 통해 스웨덴 정부에 의해 적용된 상승 시장 확약(advance market commitments), ODA와 민간 단체들 간의 협조 융자를 의미하는 민관협력(private-public partnerships)등의 수단들이 있 으며 이중 민관협력의 대표적인 펀드로는 PIDG를 들 수 있다. 


\section{사례. 민간인프라개발그룹(The Private Infrastructure Development Group; 이하 PIDG)}

PIDG는 개도국의 경제성장 촉진 및 빈곤퇴치를 위해 필수적인 인프라 제공에 있어 개도국을 지원하는 민간 부문 투자를 동원하기 위해 2002년 설립된 공여기관 출자그룹(donor-financed group)이다. 참여 공여기관 의 멤버로는 호주 외교통상부(australian government department of foreign affairs and trade), 영국 DfID, IFC, KfW, 네덜란드 외교부, Sida 등이 있다. PIDG는 민관파트너십(Public-Private Partnership)으로써 몇 개의 특수 파이낸싱 및 프로젝트 개발 자회사를 설립하였으며, 이는 민간부문의 효율성과 자본을 공급하기 위한 능력을 활용하기 위해 기획되었다. PIDG가 지원하는 모든 프로젝트는 경제, 사회, 환경 기준에 맞춰 엄 격하게 평가되며, 각 자회사가 지난 민간부문의 전문성을 활용하여 민간 투자를 진행한다. PIDG의 자회사로 는 Technical Assistance Facility, DevCo, InfraCo Africa Ltd., InfraCo Asia 등이 있다.

\section{KOICA 민간파트너십 사업을 위한 제언}

\section{1. $\mathrm{KOICA}$ 의 민간파트너십 프로그램}

민간과의 파트너십과 관련하여 KOICA는 2011년부터 '공공-민관 파트너십(public-private partnership)' 프로그램을 실시하였으며, 이는 '글로벌사회공헌프로그램(global CSR programme)' 이라는 이름을 거쳐 현재 '기업협력프로그램(business partnership programme)'이라는 명칭 아래 진행 중에 있다. 해당 사업은 MDGs달성을 위하여 민간과 파트너십을 확대함으로써 ODA 사업의 효 율성 강화, 재원의 다양화 도모, 사회문제 해결과 기업의 핵심경쟁력 강화를 동시에 달성하는 공유 가치창출(CSV)개념 확산에 목적을 두고 있다.

본 프로그램의 재원 조달 방식은 민간부문이 먼저 자체적으로 수요조사를 실시하여 형성한 사업 에 대해서 매칭펀드 방식으로 진행되며 총사업비의 일부를 KOICA가 지원금 형태로 지원한다. 2012 년 모집사업까지는 총사업비의 최대 $50 \%$ 혹은 지원금 총액의 최대 5 억 원 내로 사업비의 일부를 지 원금 형태로 지원하는 형식을 취했지만, 2015년 현재는 기업의 규모에 따라 대기업 혹은 중견기업 의 경우, 지원 상한액은 5 억 원이며, $\mathrm{KOICA}$ 지원금과 자체자금이 $5: 5$ 의 비율로 투입된다. 따라서, 기업이 5 억원을 투입할 경우, 총 사업비는 10 억원까지 가능하다. 반면, 중소기업 혹은 사회적기업의 경우 역시도 $\mathrm{KOICA}$ 의 지원 상한액은 5 억원이며, $\mathrm{KOICA}$ 지원금과 자체자금이 7:3으로 배정되어 있어 중소기업보다 $\mathrm{KOICA}$ 의 지원 비중이 높다. 
위에 언급한 사업은 한국의 기업과 파트너십을 통해 진행되는 사업인 반면, 협력국 내 중소기업을 지원하는 민간 파트너십 사업 또한 올해부터 시작되었다. $\mathrm{KOICA}$ 는 작년 11월 미국의 비영리기관 망 고펀드(mango fund $)^{7}$ 와 양해각서(MOU)를 체결하고 처음으로 임팩트 투자(impact investment) 사업)인 '우간다 중소기업 금융접근성 개선사업'을 시작하였다. 동 사업은 3 년 단위 사업으로써 2017년까지 진행되며, 대부분의 개도국 내 중소기업들이 담보 및 금융지식 등의 부재로 인하여 비공 식금융권에서 월 8 25\%에 해당하는 고금리의 이자율을 감당하며 대출을 받음으로써 기업 운영에 어려움을 겪는 현실을 반영하여 우간다 내 중소기업 육성을 통한 경제사회 발전에 이바지하기 위한 목적으로 기획되었다. 해당 사업은 KOICA 35만 불과 Mango Fund가 15 만 불을 지원하여 총 50 만 불 규모의 기금을 조성하고, 올해 1 월부터 사업에 착수하여 현재 우간다 6 개의 중소기업에 투자를 진행하고 있다. KOICA 펀드는 기업의 상황에 맞추어 이자율 월 $2 \sim 5 \%$ 및 상환기간(6 36개월)을 상이하게 책정하고 있으며, 해당 중소기업 내 일자리 창출의 극대화를 목적으로 중장비 등의 자산에 중점적으로 투자한다. 또한, 기업의 지속가능한 운영을 위하여 고객의 니즈에 따라 재무, 법률, 마케 팅 등과 관련된 맞춤형 컨설팅 또한 포함하고 있다.

KOICA의 분담금은 Mango Fund에 증여(grant)형식으로 지급되었으며, 동 기금은 중소기업에 대출되는 자금이 상환되면, 재투자하는 회전기금(revolving fund) 형식으로 운영된다. KOICA는 평 균 대손율을 $20 \%$ 로 책정하고, Mango Fund가 연간 제공하는 맞춤형 컨설팅 및 사업종료 평가 비용 까지 포함하여 프로젝트 종료 후 KOICA 분담금이 모두 소진될 수 있도록 하였다.

\section{KOICA에 제안하는 시사점}

지금까지 KOICA에서는 단기간 내에 지속적으로 혁신적 민관협력 프로그램을 기획하고 발굴해왔 으며, 이와 같은 노력이 전통적 수혜형식의 CSR프로그램에서 최근 CSV개념을 도입한 사업 및 임팩 트 투자 사업까지 많은 변화를 가져온 것이 사실이다. 그러나 SDGs의 수립과 이번 개발 재원총회의 결과를 토대로 우리나라 역시 다양한 재원을 활용하여 효과성 및 효율성을 증진시키는 새로운 형태 의 사업을 기획해야 하는 필요성을 갖게 되었다. 따라서 보다 혁신적이고 효율적인 민관협력 사업을 위해서 다음과 같은 몇 가지 사항을 제안한다.

7) 망고펀드는 2011년 미국에 설립된 비영리기관으로, 동아프리카 지역 중소기업 지원을 통한 경제 발전에 이바지하 기 위하여, 우간다에 첫 지부를 설립하고 중소기업들에 금융 대출 및 기업성장에 필요한 맞춤형 컨설팅(technical assistance)을 실시하고 있다.

8) 임팩트투자는 사회적, 환경적 개발목표와 금융의 목표를 결합하는 투자로써 지속가능한 발전을 위한 민간부문의 성 장이 필수적이라는 아이디어에 기반한다. 특히 중소기업의 발전을 지원하기 위해서는 장기적이고 지속적인 투자가 필요하므로 임팩트투자를 이를 위한 대안적이고 유망한 신개념 패러다임으로 간주되고 있다. 
첫째, 지속가능한 발전을 위해 장기적으로 민간 재원을 동원할 수 있는 방안을 마련할 필요가 있 다. 현재 진행 중인 '기업협력프로그램'의 매칭펀드 방식의 경우, 민간부문이 이미 사업을 형성하고 예산 규모를 책정하여 KOICA와의 지원을 요청하는 방식이므로 원조기관이 원조를 활용하여 기업의 재원을 동원할 수 있는 것은 최대 $1: 1$ 혹은 (중소기업의 경우)그 미만인 상황이다. 또한 이는 사업의 형성 과정 안에 재원마련의 확대 가능성에 대한 논의가 포함되지 않으므로 원조를 촉매제로 활용한 민간 재원의 동원 효과에는 한계가 있다고 생각한다. 또한 사업년도 역시 단년도 사업이거나 혹은 다년도 일 경우 최대 3 년이기에 사업 종료 후의 민간 재원의 장기적 동원 결과 및 효과를 예측하기가 어려운 것이 현실이다. 따라서, 타 원조기관의 민간재원 동원 사례에 활용된 다양한 유형의 사업 모 델 및 금융 수단을 조사 분석이 사전적으로 수행되어야 한다.

둘째, 기존에 파일럿으로 진행 중인 민간파트너십 프로그램 내에 더 많은 개발 영향을 창출하기 위하여 사업의 규모화(scale-up)와 재적용(replication)할 수 있는 혁신적 방안을 발굴하고 발생 가 능한 이슈들을 사전에 고려해야 한다. 따라서 보다 규모가 큰 민간파트너십 사업 수행에 대한 선행 학습을 하는 것이 중요하다고 판단된다. 이는 이미 관련 경험을 축적한 DfID, Sida, USAID와 같은 타 원조기관 혹은 다자기구와의 협력 사업에 참여함으로써 경험을 쌓는 것을 제안한다.

셋째, 개발협력의 전문성을 가진 기관으로써 개발성과를 철저하게 모니터링 할 수 있는 민간파트 너십만을 위한 책무성 메커니즘을 수립해야 한다. $\mathrm{KOICA}$ 는 민간파트너십 프로그램에서 협력국의 빈곤층에 가장 많은 혜택이 돌아갈 수 있는 포용적 성격의 사업을 이끌어야 하는 중요한 역할이 있 다. 민간과의 파트너십은 여러 장점도 있는 반면 예상치 못한 위험도 곳곳에 있음에 따라 발생 가능 한 여러 가지 종류의 위험에 대한 사전에 고려하여 대응할 수 있는 방안이 마련되어야 한다. 민간참 여자의 입장에서는 개도국의 정치적, 사회적 및 경제적 위험에 대한 분석이 필요하며, $\mathrm{KOICA}$ 와 협 력국의 입장에서도 민간부문 참여의 긍정적 개발 성과는 무엇인지, 실질적인 개발성과를 이루지 못 할 뿐만 아니라 부정적 영향을 가져올 수 있는 요소가 있는지를 사전에 파악하고 이에 대응할 수 있 는 가이드라인 혹은 이를 올바로 측정할 수 있는 모니터링 평가 프레임워크를 수립할 필요가 있다. 


\section{〈참고문헌〉}

\section{국내문헌}

강경아, 김진환, 오수현. 2014. "KoFID 포스트 분과 이슈브리프 Post-2015와 기업". "Ko FID Post-2015분과 Issue Brief」14호. 국제개발협력시민사회포럼

곽재성. 2012. “국제개발과 민관협력, 이슈와 정책제언”. 『국제개발협력」2012년 1호. 성남: 한국국제협력단.

기경석 외. 2015. 『지속가능개발목표(SDGs) 수립현황과 대응방안」. 성남: 한국국제협력단. 박수영, 오수현. 2015. "제 3 차 개발재원총회와 아디스아바바 행동계획의 함의 분석". 『개발과 이슈』24호. 성남: 한국국제협력단.

최민경. 2008. 『우리나라 개발원조의 민관협력 활성화 방안-PPP와 개발컨설턴트 활용을 통 한 민간과의 파트너십 강화. 성남: 한국국제협력단.

\section{국외문헌}

Bilal, San. Byiers, Bruce. Grobe-Puppendahl, Sebastian. Krat ke, Florian. Nubong, Gabila. and Rosengren, Anna. 2014. "De-coding Public-Private Partnerships for Development”. "Discussion Paper». No.161. European Centre for Developmnet Policy Centre.

Billing, Annika. Forslind, Maja. and Cueva, Karin Metell. 2012. "Swedish Development Cooperation and the Private Sector-The role of business in poverty alleviation and the role of donors in promoting private sector contributions to development". "Perspectives». No. 22. University of Gothenburg.

Devfin Advisers. 2014. "Innovative Finance Gap Analysis".

Griffiths, Jesse. 2015. "Financing for development: Key challenges for policy makers". European Network on Debt and Development.

Kharas, Homi. 2013. "Reimagining the Role of the Private Sector in Development". OECD. 2015. "Chapter 4. Private sector partneships for sustainable development". "Development Cooperation Report 2015: Making Partnerships Effective Coalitions for Action. OECD. 
PIDG. 2015. 『PIDG Annual Report 2014』. Private Investment Development Group.

Sida. "Innovative Financing-Collaboration with the private \& public sector". Sida.

UN. 2003. "Monterrey Consensus of the International Conference on Financing for Development. The final text of agreement and commitments adopted at the International Conference on Financing for Development".

. 2008. "Doha Declaration on Financing for Development: outcome document of the Follow-up International Conference on Financing for Development to Review the Implementation of the Monterrey Consensus". 2015. "Outcome document of the Third International Conference on Financing for Development: Addis Ababa Action Agenda”.

World Bank. 2015. "From Billions to Trillions: Transforming Development Finance Post-2015 Financing for Development; Multilateral Development Finance”. Development Committee Discussion Note. 